\title{
ANALISIS KEDUDUKAN KETERANGAN KORBAN TERKAIT KEJAHATAN TERHADAP HARTA KEKAYAAN DALAM LINGKUNGAN KELUARGA: SEBUAH ANTINOMI ANTARA HUKUM MATERIL DENGAN FORMIL
}

\author{
Peter Jeremiah Setiawan, Xavier Nugraha, Michael Enrick
}

Fak. Hukum Universitas Surabaya, Fak. Hukum Universitas Airlangga

Correspondent E-Mail: peterjsetiawan@staff.ubaya.ac.id

\begin{abstract}
Crimes against property are crimes that can also occur within a family. The crimes against property within a family itself are materially a crime that has more specific rules as it is set forth under Article 367 and Article 376 of the Indonesia Criminal Code, that crimes committed within the scope of the family are crimes based on complaint. The position as a complainant has specifically placed the family as a victim as a basis for the law enforcement process of the crime against assets within a family. The legal standing of the family as the victim and the complainant as an important aspect determined by the material law is not adopted by formal law which is for the enforcement of the crime. In contrast to the Indonesia Criminal Code which places the family as an important aspect in the specificity of crimes against property in the scope of the family, Article 168 of the Indonesia Criminal Procedure Code provides a threat to the value of the evidence of the testimony given by witnesses who have family relations with the perpetrators. The antinomy that exists between material and formal law then underlies two legal issues, which is about the position of witness testimony in the evidentiary procedure of criminal law in Indonesia and the position of victim testimony related to crimes against property in a family in Indonesia.
\end{abstract}

Keywords:

Crime against property within a family: witness testimony; value of the evidence/an evidence; evidences 


\begin{abstract}
Abstrak
Kejahatan terhadap harta kekayaan merupakan kejahatan yang dapat pula terjadi dalam lingkup keluarga. Kejahatan terhadap harta kekayaan dalam lingkup keluarga sendiri secara materiil merupakan tindak pidana yang memiliki aturan yang lebih khusus dan spesifik dalam Pasal 367 dan Pasal 376 KUHP, dimana Kejahatan yang dilakukan dalam lingkup keluarga tersebut merupakan delik aduan. Kedudukannya sebagai delik aduan telah secara khusus menempatkan keluarga sebagai korban sebagai acuan terhadap proses penegakan hukum kejahatan terhadap harta kekayaan. Pentingnya keluarga selaku korban dan pengadu sebagai aspek penting yang ditetapkan hukum materiil tersebut nyatanya tidak dianut hukum formil dalam penegakannya. Berbeda dengan KUHP yang menempatkan keluarga sebagai aspek penting dalam kekhususan kejahatan terhadap harta kekayaan dalam lingkup keluarga, Pasal 168 KUHAP justru memberikan ancaman terhadap nilai pembuktian keterangan yang diberikan oleh saksi yang memiliki hubungan keluarga dengan pelaku. Antinomi yang ada diantara hukum materiil dan formil ini selanjutnya melandasi dua masalah hukum, yaitu mengenai kedudukan keterangan saksi dalam pembuktian hukum pidana di Indonesia dan kedudukan keterangan korban terkait kejahatan terhadap harta kekayaan dalam lingkungan keluarga di Indonesia.
\end{abstract}

\title{
Kata Kunci:
}

Kejahatan terhadap harta kekayaan dalam lingkup keluarga; Keterangan saksi; NIlai pembuktian; Alat Bukti.

\section{A. PENDAHULUAN}

Manusia sebagai makhluk sosial, seharusnya saling tolong menolong satu sama lain, malah berubah menjadi makhluk yang tidak pernah puas dalam memenuhi kebutuhan hidupnya. Keadaan ini melahirkan antitesis dari konsep manusia yang dulunya adalah homo homini socius menjadi manusia adalah homo homini lupus yang berarti manusia adalah serigala bagi sesamanya. ${ }^{1}$ Perubahan kondisi sosial manusia yang saling berusaha untuk menjatuhkan satu sama lain secara tidak langsung juga meningkatkan kebutuhan-kebutuhan manusia tersebut

${ }^{1}$ Marcus Vinicius Xavier de Oliveira, Os Direitos Absolutos No Contexto Do Direito Internacional Dos Direitos Humanos, Revista jurídica de la Secretaría del Tribunal Permanente de Revisión, Vol 7, No.13, Maret 2019,h. 107. 
sehari-hari, karena manusia yang dulunya berusaha untuk saling memenuhi kebutuhan, kini berusaha untuk memenuhi kebutuhannya secara individu. Terlepas dari kebutuhan yang ada adalah kebutuhan primer, sekunder, maupun tersier, sesungguhnya kebutuhan itu terus bertambah. Hal-hal yang dulunya adalah kebutuhan tersier, kini bahkan berubah menjadi kebutuhan primer. Salah satu perubahan tersebut adalah internet. Seiring dengan berubahnya zaman, maka kebutuhan internet ini bisa berubah menjadi kebutuhan primer.

Untuk memenuhi kebutuhannya, tidak sedikit orang yang menggunakan segala cara. Tekanan ekonomi sendiri dapat dikatakan memberikan tekanan besar bagi peningkatan jumlah tindak pidana. ${ }^{2}$ Tindak pidana dengan motif ekonomi sendiri cukup beragam dan mendapat perhatian khusus dalam ilmu hukum dan dikenal sebagai kejahatan terhadap harta kekayaan. Tindak pidana dalam hal harta kekayaan sendiri secara umum diatur dalam Bab XXII -XXV, XVII, XXX buku II KUHP, yaitu meliputi:

1. Pencurian (Pasal 362-367 KUHP)

2. Pemerasan dan Pengancaman (Pasal 368-371 KUHP)

3. Penggelapan (Pasal 372-377 KUHP)

4. Perbuatan curang (Pasal 378-395 KUHP)

5. Perusakan barang (Pasal 406-412 KUHP)

6. Penadahan (Pasal 480-482 KUHP)

Kejahatan terhadap harta kekayaan memang umumnya viktimisasi yang terjadi terhadap korban secara umum dalam arti tidak terdapat kriteria tertentu siapa saja yang dapat menjadi korban kejahatan terhadap harta kekayaan. Tidak menutup kemungkinan, kejahatan terhadap harta kekayaan tersebut terjadi terhadap orang-orang terdekat seperti keluarga pelaku tindak pidana. ${ }^{3}$ Kejahatan terhadap harta kekayaan yang menimbulkan viktimisasi dalam keluarga sendiri merupakan konsep yang dikenal dalam KUHP seperti, pencurian dalam lingkup keluarga dalam Pasal 367 KUHP dan penggelapan dalam lingkup keluarga dalam Pasal 376 KUHP.

Mengacu pada kekhususan kejahatan terhadap harta kekayaan dalam lingkup keluarga yang menempatkan tindak pidana tersebut sebagai delik aduan dimana terhadap tindak pidana tersebut harus dilakukan pengaduan terlebih dahulu oleh korban. Dasar pemikiran dari penempatan kejahatan terhadap harta kekayaan dalam lingkup keluarga sebagai sebuah delik aduan adalah demi mengedepankan keadilan restoratif. Keadilan restoratif mengharapkan adanya proses musyawarah agar

${ }^{2}$ Evi Yulia Purwanti dan Eka Widyaningsih, “Analisis Faktor Ekonomi Yang Mempengaruhi Kriminalitas Di Jawa Timur", JEQU, Vol. 9, No. 2 (2019), h. 157. <http://jurnal.untirta.ac.id/i ndex.php/Ekonomi-Qu>

3 Sri Hartini, "Korban Penyalahgunaan Kewenangan Rezim Orde Baru”, Journal Civics, Vol.4 No. 2 (2007), h. 60. <https://journal.uny.ac.id/index.php/civics/article/downloadSuppFile/6030/926> 
didapat penyelesaian antara korban dan pelaku tindak pidana dan korban tindak pidana demi memulihkan akibat yang ditimbulkan. ${ }^{4}$

Penempatan kekhususan kejahatan terhadap harta kekayaan dalam lingkup keluarga ternyata menimbulkan antinomi antara hukum pidana materiil dengan hukum pidana formil. Jika merujuk pada ketentuan di dalam Kitab Undang-Undang Hukum Pidana (KUHP), kejahatan terhadap harta kekayaan dalam lingkup keluarga menempatkan anggota keluarga pelaku sebagai korban tindak pidana yang secara logis tentunya eksistensi keterangannya saksi tersebut wajib ada. Hal tersebut, seolah bertentangan dengan ketentuan dalam hukum pidana formil pada Pasal 168 Undang Undang Nomor 8 Tahun 1981 Tentang Hukum Acara Pidana (KUHAP) yang mengatur, bahwa keluarga pelaku tindak pidana “...tidak dapat didengar keterangannya..."

Adanya antinomi antara pentingnya keterangan anggota keluarga tersebut sebagai korban dan aturan yang membatasi pemberian keterangan saksi oleh keluarga menimbulkan dilematika hukum. Pada satu sisi, kedudukan keterangan korban pada kejahatan terhadap harta kekayaan dalam lingkup keluarga merupakan hal yang penting, karena deliknya merupakan delik aduan relatif, namun di sisi lain terdapat ketentuan pada Pasal 168 KUHAP yang berpotensi membuat keterangannya tidak bernilai sebagai alat bukti. Hal ini sungguh amat membingungkan, karena pada kejahatan terhadap harta kekayaan dalam lingkup keluarga, korbannya pasti merupakan anggota keluarga dari pelaku. Hal ini menimbulkan problematika hukum terkait nilai pembuktian dan kedudukan keterangan korban yang notabene juga merupakan anggota keluarga dari pelaku dalam kejahatan terhadap harta kekayaan dalam lingkup keluarga tersebut. Berdasarkan latar belakan tersebut, rumusan masalah dalam penelitian ini adalah:

1. Bagaimana kedudukan keterangan saksi dalam pembuktian hukum pidana di Indonesia?

2. Bagaimana kedudukan keterangan korban terkait kejahatan terhadap harta kekayaan dalam lingkungan keluarga di Indonesia?

\section{A. METODE PENELITIAN}

Penelitian ini adalah penelitian hukum. Menurut Soerjanoe Soekantoe, penelitian hukum adalah penelitian terhadap suatu kejadian ilmiah, yang dianalisis dengan mendasarkan pada metode, sistematika, dan pemikiran tertentu, yang bertujuan untuk mempelajari satu atau beberapa gejala hukum dengan jalan

${ }^{4}$ Rr. Susana Andi Meyrina, Restorative Justice Dalam Peradilan Anak Berdasarkan UndangUndang No.11 Tahun 2012, Jurnal Penelitian Hukum De Jure, Vol 17, No.1, Maret 2017,h. 93. 
menganalisisnya dengan menggunakan argumentasi hukum. ${ }^{5}$ Penelitian hukum dengan menggunakan argumentasi hukum, berarti penelitian hukum tersebut adalah penelitian yang fokus utamanya adalah mengkaji pemberlakuan suatu aturan hukum dengan disertai argumentasi/pertimbangan hukum yang dibuat penegak hukum, serta interpretasi di balik pemberlakuan suatu putusan yang memiliki koherensi dengan pemberlakuan aturan hukum tersebut. ${ }^{6}$

Menurut Peter Mahmud Marzuki, terdapat beberapa pendekatan dalam penelitian hukum, yaitu: ${ }^{7}$

1. Pendekatan Peraturan Perundang-undangan (Statute Approach);

2. Pendekatan Konseptual (Conceptual Approach);

3. Pendekatan Kasus (Case Approach);

4. Pendekatan Historis (Historical Approach); dan

5. Pendekatan Komparatif (Comparative Approach).

Dalam penelitian hukum ini, pendekatan yang digunakan adalah pendekatan peraturan perundang-undangan, kasus, dan konseptual. Pendekatan peraturan perundang-undangan dilakukan dengan menelaah semua peraturan perundangundangan dan regulasi yang berkaitan dengan isu hukum yang dianalisis. ${ }^{8}$ Dalam penelitian ini, peraturan perundang-undangan yang digunakan adalah peraturan perundang-undangan yang berkaitan dengan kedudukan keterangan korban terkait kejahatan terhadap harta kekayaan dalam lingkungan keluarga.

Pendekatan konseptual dilakukan beranjak dari pandangan-pandangan dan doktrin-doktrin yang berkembang di dalam ilmu hukum. ${ }^{9}$ Dengan mempelajari pandangan-pandangan dan doktrin-doktrin akan ditemukan ide-ide yang melahirkan pengertian-pengertian hukum, konsep-konsep hukum dan asas-asas hukum yang relevan dengan isu hukum yang dihadapi. ${ }^{10}$ Konsep-konsep hukum yang dianalisis dalam penelitian ini adalah yang berkaitan dengan keterangan korban terkait kejahatan terhadap harta kekayaan dalam lingkungan keluarga.

${ }^{5}$ Soerjono Soekanto, Pengantar Penelitian Hukum, (Jakarta: UI Press,1989), h.43.

6 Xavier Nugraha, Risdiana Izzaty, dan Annida Aqila, Rekonstruksi Batas Usia Minimal Perkawinan Sebagai Bentuk Perlindungan Hukum, Lex Scientia, Vol. 3, No. 1, Mei 2019, h. 40-54.

${ }^{7}$ Peter Mahmud Marzuki, Penelitian Hukum Edisi Revisi, (Jakarta: Kencana Prenada Media,2005), h.93.

\footnotetext{
8 Peter Mahmud Marzuki, Penelitian Hukum Edisi Revisi, h.93.

${ }^{9}$ Peter Mahmud Marzuki, Penelitian Hukum Edisi Revisi, h.93.

${ }^{10}$ Peter Mahmud Marzuki, Penelitian Hukum Edisi Revisi, , h.93.
} 
Pendekatakan putusan menggunakan putusan hakim sebagai sumber bahan hukum. ${ }^{11}$ Putusan hakim yang digunakan adalah putusan hakim yang telah memiliki kekuatan hukum tetap (inkracht van gewijsde). Pada saat membahas putusan pengadilan sebagai bahan hukum primer, maka yang dianalisis adalah pada bagian ratio decedendi-nya, yang notabene merupakan alasan hukum yang digunakan oleh hakim dalam menentukan putusannya (pertimbangan hakim). ${ }^{12}$ Dalam penelitian ini putusan yang dianalisis adalah yang memiliki korelasi dengan keterangan korban terkait kejahatan terhadap harta kekayaan dalam lingkungan keluarga, seperti Putusan Pengadilan Negeri Sidoarjo Nomor 835/Pid.B/2010/PN.Sda. terkait pencurian dalam keluarga dan Putusan Pengadilan Negeri Pematang Siantar Nomor 102/Pid.B/2018/PN Pms terkait penggelapan dalam keluarga.

\section{B. HASIL PENELITIAN DAN PEMBAHASAN}

\section{Kedudukan keterangan saksi dalam pembuktian hukum pidana di Indonesia}

Pembahasan mengenai saksi dan keterangan saksi merupakan konsep penting dalam pembuktian yang dianut dalam hukum acara pidana. Mengacu pada Pasal 1 angka 26 KUHAP definisi saksi dalam hukum pidana diberikan secara limitatif sebagai berikut:13"Saksi adalah orang yang dapat memberikan keterangan guna kepentingan penyidikan, penuntutan dan peradilan tentang suatu perkara pidana yang ia dengar sendiri, ia lihat sendiri dan ia alami sendiri". Sedangkan keterangan saksi menurut Pasal 1 angka 27 KUHAP adalah: ${ }^{14}$ “... salah satu alat bukti dalam perkara pidana yang berupa keterangan dari saksi mengenai suatu peristiwa pidana yang ia dengar sendiri, ia lihat sendiri dan ia alami sendiri dengan menyebut alasan dari pengetahuannya itu".

Bahwa berdasarkan definisi yang ditetapkan KUHAP terhadap saksi dan keterangan saksi, maka didapat sebuah simpulan yang sifatnya limitatif terhadap siapa saja yang sebenarnya dapat dijadikan sebagai saksi. Saksi haruslah melihat, mendengar, dan/atau mengalami sendiri suatu perkara pidana, sehingga secara argumentum a contrario seorang yang tidak melihat sendiri, mendengar sendiri, dan

${ }^{11}$ Faizal Kurniawan, Xavier Nugraha, Bagus Oktafian Abrianto, Syifa Ramadhanti, The Right To Access Banking Data In A Claim For A Division Of Combined Assets That Is Filed Separately From A Divorce Claim Yustisia, Vol. 9, No. 1, April 2020, h. 52.

${ }^{12}$ Faizal Kurniawan, Xavier Nugraha, Bagus Oktafian Abrianto, Syifa Ramadhanti, The Right To Access Banking Data In A Claim For A Division Of Combined Assets That Is Filed Separately From A Divorce Claim Yustisia, Vol. 9, No. 1, April 2020, h. 52.

13 Oktavianus Garry Runtuwene, "Hak Dan Kewajiban Yang Mengikat Terhadap Saksi Di Dalam Praktik Persidangan Pidana, Lex Crimen, Vol.I No.4 (2012), h.143. < https://media.neliti. com/media/publications/3167-ID-hak-dan-kewajiban-yang-mengikat-terhadap-saksi-di-dalampraktik-persidangan-pida.pdf>

${ }^{14}$ Remincel, "Kedudukan Saksi Dalam Hukum Pidana", Ensiklopedia of Journal, Vol. 1 No.2 Edisi 2 (2019), h.270. (http://jurnal.ensiklopediaku.org ) 
mengalami sendiri suatu peristiwa pidana tidak dapat menjadi saksi dan memberikan keterangan saksi pada sidang pidana. ${ }^{15}$ Definisi demikian adalah sesuai dengan prinsip non testimonium de auditu, yang berarti, bahwa keterangan saksi dalam sidang pengadilan tidak boleh mengenai hal yang ia dengar dari orang lain. ${ }^{16}$ Terkait larangan saksi tidak boleh memberikan keterangan berdasarkan keterang orang lain, sejatinya juga diatur di dalam penjelasan Pasal 185 ayat (1) KUHAP yang berbunyi: "Dalam keterangan saksi tidak termasuk keterangan yang diperoleh dari orang lain atau testimonium de auditu."

Disamping ketentuan tersebut diatas, nyatanya dalam praktik hukum acara pidana di Indonesia dikenal juga saksi-saksi yang tidak mendengar, melihat, maupun mengalami langsung suatu tindak pidana. Adapun saksi-saksi yang tidak melihat, mendengar, maupun mengalami peristiwa pidana tersebut, dalam praktik hukum acara pidana tetap diakui dan didengarkan keterangannya. Saksi ini, disebut sebagai saksi verbalisan. Saksi verbalisan atau saksi penyidik merupakan saksi yang dihadirkan dalam persidangan dalam hal Terdakwa mencabut keterangan yang telah diberikan dalam Berita Acara Pemeriksaan (BAP). Walaupun tidak diatur dalam KUHAP, namun kehadiran Saksi verbalisan ini menjadi penting untuk membuktikan alasan Terdakwa mencabut keterangan dalam BAP, yaitu apakah benar saat BAP diberikan Terdakwa ada dibawah tekanan. ${ }^{17}$

Perkembangannya, definisi saksi mendapat perluasan makna. Saksi tidak lagi terbatas kepada orang-orang yang melihat, mendengar, dan mengalami sendiri suatu tindak pidana. Perubahan pemaknaan terhadap siapa saja yang dapat menjadi saksi ini sesuai dengan Putusan Mahkamah Konstitusi RI Nomor 65/PUU-VIII/2010. Putusan Mahkamah Konstitusi RI Nomor 65/PUU-VIII/2010 menyatakan, bahwa definisi Saksi dan Keterangan Saksi dalam Pasal 1 angka 26 dan 27 KUHAP adalah inkonstitusional, sepanjang tidak dimaknai bahwa saksi tidak terbatas pada orang yang melihat, mendengar dan mengalami langsung peristiwa pidana. ${ }^{18}$

Terlepas dari perluasan makna saksi, perlu diperhatikan bahwa tidak semua saksi dapat didengar keterangannya di muka pengadilan. Berdasarkan Pasal 168

15 Remincel, "Kedudukan Saksi Dalam Hukum Pidana”, Ensiklopedia of Journal, Vol. 1 No.2 Edisi 2 (2019), h.270. (http://jurnal.ensiklopediaku.org )

16 Asprianti Wangke, "Kedudukan Saksi De Auditu Dalam Praktik Peradilan Menurut Hukum Acara Pidana”, Lex Crimen, Vol VI No. 6 (2017), h.147. <https://media.neliti.com/media/publications/ 147591-ID-kedudukan-saksi-de-auditu-dalam-praktik.pdf>

17 Azharia Putty Alamanda, "Kesesuaian Penggunaan Saksi Verbalisan Serta Pertimbangan Hukum Hakim Dalam Menjatuhkan Putusan (Studi Putusan Nomor 1131/Pid.An/2013/Jkt.Sel),Jurnal Verstek, Vol. 5 No. 3 (2017), h. 105. <https://jurnal.uns.ac.id/verstek/article/viewFile/33524/22118>

${ }^{18}$ Steven Suprantio, "Daya Ikat Putusan Mahkamah Konstitusi Tentang "Testimonium de Auditu"”, Jurnal Yudisial Vol. 7 No. 1 (2014), h. 34 - 52. <https://jurnal.komisiyudisial.go.id/ index.php/jy/article/viewFile/92/76> 
KUHAP terdapat tiga kelompok orang yang tidak dapat didengar keterangannya, yaitu:

1. Keluarga sedarah dan semenda terdakwa dan pelaku penyertaan dalam tindak pidana di mana terdakwa didakwa. Ada pun keluarga sedarah dan semenda yang tidak dapat didengar keterangannya sebagai saksi dalam hukum acara pidana adalah hubungan sedarah dan semenda ke atas dan ke bawah hingga derajat ketiga;

2. Saudara, saudara ayah, saudara ibu, anak-anak saudara, dan mereka yang memiliki hubungan karena perkawinan dari terdakwa dan pelaku penyertaan dalam tindak pidana di mana terdakwa didakwa;

3. suami atau istri, baik yang telah cerai maupun masih berstatus suami istri dengan terdakwa dan pelaku penyertaan dalam tindak pidana di mana terdakwa didakwa.

Sekalipun pada dasarnya orang yang termasuk dalam tiga kelompok tersebut pada dasarnya tidak dapat didengarkan keterangannya dalam persidangan, namun perlu diperhatikan frasa yang digunakan dalam Pasal 168 KUHAP yaitu "Kecuali ditentukan lain dalam undang-undang ini, maka tidak dapat didengar keterangannya dan dapat mengundurkan diri sebagai saksi". Formulasi Pasal 168 KUHAP tersebut sebenarnya merupakan penormaan prinsip tidak berwenang memberikan kesaksian secara relatif. ${ }^{19}$ Sekalipun pada dasarnya tidak dapat didengarkan keterangannya, namun terdapat keadaan tertentu dimana tiga kelompok tersebut dapat didengarkan keterangannya sebagai saksi, yaitu sebagaimana dimaksud dalam Pasal 169 ayat (1) KUHAP. Dalam Pasal 169 ayat (1) KUHAP, diatur, bahwa ketiga kelompok orang tersebut dapat memberikan keterangan dibawah sumpah sepanjang mendapat persetujuan dari penuntut umum dan terdakwa. Sedangkan dalam hal saksi tidak mendapat persetujuan dari penuntut umum atau terdakwa, maka berdasarkan Pasal 169 ayat (2) KUHAP keterangan saksi tersebut dapat didengarkan tanpa disumpah.

Nyatanya, seolah-olah terdapat kontradiksi antara frasa yang digunakan dalam Pasal 168 KUHAP antara "tidak dapat didengar keterangannya" dan "dapat mengundurkan diri sebagai saksi". Mengacu pada Pasal 168 KUHAP yang dihubungkan dengan Pasal 169 ayat (1) dan (2) KUHAP, maka seorang yang termasuk dalam 3 kelompok yang disebutkan dalam 168 KUHAP tersebut lah yang dapat menentukan apakah dirinya hendak memberikan keterangan di muka persidangan atau mengundurkan diri sebagai saksi, sedangkan peran persetujuan penuntut umum dan terdakwa dalam kehadirannya sebagai saksi hanya menentukan apakah saksi memberikan keterangan dibawah sumpah atau tanpa

${ }^{19}$ Lilik Mulyadi, Hukum Acara Pidana, (Bandung:PT Citra Aditya Bakti, 2007), h. 68. 
diambil sumpah. ${ }^{20}$ Berikut adalah skema untuk memudahkan pemahaman terkait saksi ini:

Saksi

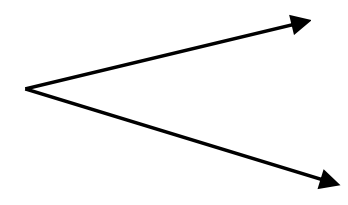

Skema 1. Kehadiran Saksi

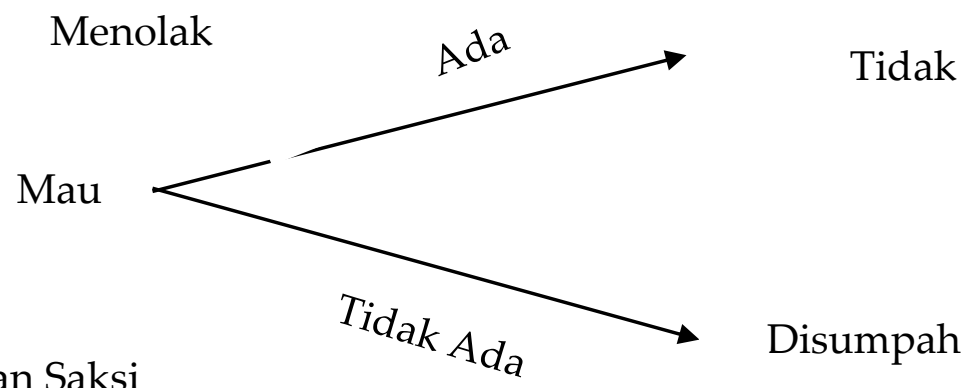

Hukum acara pidana menempatkan sumpah sebagai parameter penting terkait kedudukan keterangan saksi. Secara umum, mengacu pada ketentuan Pasal 184 ayat (1) KUHAP dan 185 ayat (1) KUHAP, keterangan saksi sepanjang diberikan dimuka persidangan merupakan alat bukti yang sah. Urgensi dari disumpah atau tidaknya seorang saksi yang memberikan keterangan di muka persidangan dalam kaitannya dengan hukum acara pidana dapat ditemukan dalam ketentuan Pasal 185 ayat (7) KUHAP, yaitu "Keterangan dari saksi yang tidak disumpah meskipun sesuai satu dengan yang lain, tidak merupakan alat bukti...". Penempatan keterangan saksi yang diberikan dibawah sumpah memiliki nilai pembuktian yang lebih jelas dibandingkan keterangan saksi yang tidak disumpah adalah berdasarkan pemikiran bahwa keterangan saksi yang diberikan dibawah sumpah lebih dapat dipercaya dan lebih terjamin. Menurut Adami Chazawi keterangan saksi dibawah sumpah terjamin berdasarkan dua alasan yaitu ${ }^{21}$ :

1. Sebagai bangsa yang sangat religius dan hidup bermasyarakat berdasarkan prinsip ketuhanan maka timbul kepercayaan akan dosa dan kutukan terhadap perbuatan melanggar sumpah; dan

2. Pemberian keterangan dibawah sumpah bukan hal remeh, sedangkan pemberian keterangan dengan sumpah palsu diancam pidana dalam Pasal 242 KUHP.

Sekalipun kehadiran saksi yang termasuk dalam 3 kelompok saksi yang tidak dapat didengar keterangannya tersebut umumnya akan ditolak oleh pihak yang akan dirugikan oleh keterangan saksi tersebut sehingga keterangannya akan diberikan tanpa diambil sumpah, namun tidak berarti keterangan saksi tersebut tidak memiliki nilai pembuktian. Berdasarkan Pasal 1 angka 27 KUHAP jo. Putusan Mahkamah Konstitusi RI Nomor 65/PUU-VIII/2010, semua hal yang diterangkan

\footnotetext{
${ }^{20}$ Lilik Mulyadi, Hukum Acara Pidana, h. 66-67.

21 Adami Chazawi, Hukum Pembuktian Tindak Pidana Korupsi, (Bandung: PT.Alumni, 2008), h.
} 50-51. 
saksi di muka pengadilan, merupakan keterangan saksi. Selanjutnya berdasarkan Pasal 185 ayat 7 KUHAP dalam hal keterangan saksi yang tidak diberikan dibawah sumpah berkesesuaian dengan keterangan saksi dibawah sumpah maka tetap memiliki nilai sebagai alat bukti keterangan saksi. Selain itu keterangan saksi yang sekalipun tidak diberikan dibawah sumpah, mengacu kepada pasal 188 ayat (1) dan (2) KUHAP, sepanjang terkait dengan perbuatan, kejadian, atau keadaan karena bersesuaian dengan bukti-bukti dan/atau alat bukti- alat bukti yang lain merupakan alat bukti petunjuk.

Keterangan saksi yang diberikan tidak dibawah sumpah tetap dapat bernilai pembuktian walaupun bergantung dengan alat bukti yang lain berbeda dengan alat bukti keterangan saksi dibawah sumpah yang terikat dengan Prinsip unus testis nullus testis. Prinsip unus testis nullus testis dalam hukum acara pidana Indonesia dinormakan dalam Pasal 185 ayat (2) yang berbunyi "Keterangan seorang saksi saja tidak cukup untuk membuktikan bahwa terdakwa bersalah terhadap perbuatan yang didakwakan kepadanya." Dengan dasar tersebut, pemaknaan terhadap prinsip unus testis nullus testis dalam hukum acara pidana Indonesia sendiri tidak dapat dimaknai serta merta "satu saksi bukan saksi", melainkan satu keterangan saksi (dibawah sumpah) tetap merupakan alat bukti keterangan saksi, namun tidak cukup untuk membuktikan suatu tindak pidana. ${ }^{22}$ Mengacu Pada Pasal 185 ayat (2) KUHAP maka pada dasarnya keterangan saksi merupakan alat bukti yang independen, sedangkan keberadaan keterangan saksi atau bukti yang lain merupakan bentuk pemenuhan dari teori pembuktian negatif (negatif wettelijk bewijstheorie) yang dianut dalam Pasal 183 KUHAP yang mensyaratkan setidaknya 2 (dua) alat bukti. ${ }^{23}$

Adapun prinsip keterangan saksi terkait dengan nilai pembuktiannya dapat dijabarkan sebagai berikut:

a) Berdasarkan Pasal 1 angka 27 KUHAP jo. Putusan Mahkamah Konstitusi RI Nomor 65/PUU-VIII/2010, maka apa yang dinyatakan saksi dalam sidang tetap termasuk keterangan saksi baik disumpah ataupun tanpa diambil sumpah;

b) Tidak semua keterangan saksi merupakan alat bukti dan bernilai pembuktian. Berdasarkan Pasal 185 ayat (7) dan argumentum a contrario Pasal 188 ayat (1) dan (2) KUHAP, maka keterangan saksi yang diberikan tanpa diambil sumpah dan tidak memiliki persesuaian dengan keterangan saksi dibawah sumpah(memiliki nilai pembuktian) atau alat bukti lainnya bukan merupakan alat bukti;

22 Remincel, "Kedudukan Saksi Dalam Hukum Pidana”, Ensiklopedia of Journal, Vol. 1 No.2 Edisi 2 (2019), h.270. (http://jurnal.ensiklopediaku.org), h.271.

23 Bastianto Nugroho,Peranan Alat Bukti Dalam Perkara Pidana Dalam Putusan Hakim Menurut KUHAP, Yuridika Vol. 32 No. 1 (2017), h.19. 
c) Keterangan saksi dapat bernilai pembuktian tanpa bergantung dengan alat bukti yang lain (bersifat independen), bergantung dengan alat bukti yang lain (bersifat dependen), dan tidak bergantung namun memiliki persesuaian dengan alat bukti yang lain. Berdasarkan Pasal 185 ayat (1) dan argumentum a contrario Pasal 185 ayat (7) KUHAP maka keterangan saksi dibawah sumpah secara independen memiliki nilai sebagai alat bukti keterangan saksi, sedangkan berdasarkan Pasal 185 ayat (7) KUHAP dan Pasal 188 ayat (1) dan (2) KUHAP dalam hal keterangan saksi tidak disumpah maka kekuatan pembuktiannya bergantung terhadap persesuaiannya dengan alat bukti yang lain;

d) Tidak semua keterangan saksi yang bernilai pembuktian adalah alat bukti keterangan saksi, melainkan dapat berupa alat bukti petunjuk dan dapat pula bernilai ganda sebagai alat bukti keterangan saksi dan alat bukti petunjuk. Hal keterangan saksi yang tidak diambil dibawah sumpah berkesesuaian dengan alat bukti keterangan saksi (keterangan saksi dibawah sumpah) maka bernilai pula sebagai alat bukti keterangan saksi dan dalam hal persesuaian tersebut dengan alat bukti keterangan terdakwa atau alat bukti surat maka bernilai pembuktian sebagai alat bukti petunjuk. Sedangkan keterangan saksi dibawah sumpah selain bernilai sebagai alat bukti keterangan saksi dapat pula bernilai ganda yaitu sekaligus bernilai sebagai alat bukti petunjuk.

Berdasarkan Pasal 1 angka 27 KUHAP jo. Putusan Mahkamah Konstitusi RI Nomor 65/PUU-VIII/2010 dan Pasal 185 ayat (1) dan (7) serta Pasal 188 ayat (1) dan (2) KUHAP sebagaimana prinsip-prinsipnya telah terlebih dahulu diuraikan diatas, maka didapat skema sebagai berikut:

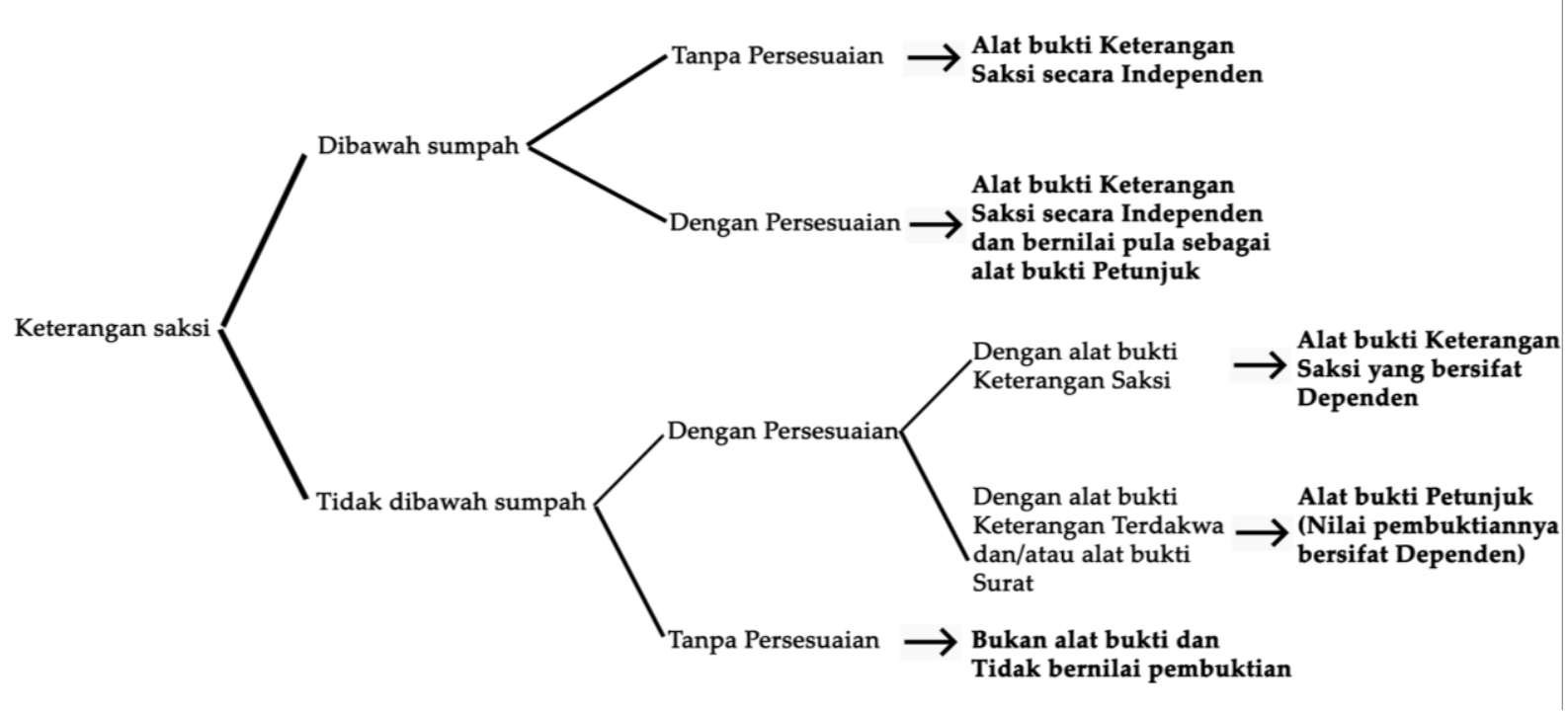

Skema 2. Keterangan saksi 
a. Adapun dapat dijabarkan berdasarkan prinsip-prinsip dan skema diatas maka keterangan saksi berdasarkan nilai pembuktiannya dapat dibedakan menjadi 5 kelompok sebagai berikut:

b. Keterangan saksi yang tidak bernilai pembuktian;

c. Keterangan saksi yang bernilai pembuktian yang sifatnya independen dan diterima sebagai alat bukti keterangan saksi (nyata bernilai pembuktian karena diberikan dalam persidangan dibawah sumpah);

d. Keterangan saksi yang bernilai pembuktian yang sifatnya dependen dan diterima sebagai alat bukti keterangan saksi (Keterangan saksi yang diberikan tanpa diambil sumpah namun berkesesuaian dengan keterangan saksi dibawah sumpah sesuai ketentuan Pasal 185 ayat (7) KUHAP);

e. Keterangan saksi yang bernilai pembuktian yang sifatnya dependen dan tidak dapat diterima sebagai alat bukti keterangan saksi, namun diterima sebagai alat bukti petunjuk (Keterangan saksi yang diberikan tanpa diambil sumpah namun berkesesuaian dengan alat bukti surat dan/atau keterangan terdakwa);

f. Keterangan saksi yang bernilai pembuktian yang sifatnya independen serta memiliki persesuaian dan diterima sebagai alat bukti keterangan saksi dan diterima pula sebagai alat bukti petunjuk.

\section{Kedudukan Keterangan Korban Sebagai Alat Bukti Saksi Terkait Kejahatan Terhadap Harta Kekayaan Dalam Lingkungan Keluarga}

Noch suchen die Juristen eine definition zu ihrem Begreiffe Von Recht. ${ }^{24}$ Sebuah kritik dari filsuf Immanuel Kant terhadap pandangan yang menganggap, bahwa segala sesuatu harus berawal dari sebuah definisi, padahal definisi bukanlah merupakan satu-satunya cara untuk menjelaskan suatu konsep, apalagi untuk konsep hukum. Kritik dari Immanuel Kant tersebut, bisa dibilang relevan dalam rangka memahami terkait dengan konsep kejahatan terhadap harta kekayaan yang ada di dalam KUHP. Di dalam KUHP, tidak ada pengaturan terkait definisi dari kejahatan terhadap harta kekayaan. Di KUHP hanya ada pengaturan terkait klasifikasi mengenai jenis-jenis kejahatan terhadap harta kekayaan yang diatur di dalam bab-bab terkait kejahatan terhadap harta kekayaan. Adapun bab-bab terkait kejahatan terhadap harta

\footnotetext{
${ }^{24}$ Wahyu Purnomo, Rr Herini Siti Aisyah, Thoriq Mulahela, Xavier Nugraha, Analysis of Lawsuit Against the Factual Action which Conducted by Military after Law Number 30 Year 2014 Concerning Government Administration, UNRAM Law Review, Vol 4, No 1, April 2020, h. 18.
} 
kekayaan yang ada di dalam KUHP antara lain adalah Bab XXII pencurian, Bab XXIII Pemerasan dan Pengancaman; Bab XXIV Penggelapan; Bab XXV Perbuatan curang; Bab XXVI merugikan orang berpiutang atau yang mempunyai hak; Bab XXVII menghancurkan atau merusak barang; Bab XXX penadahan.

Di antara kejahatan-kejahatan terhadap harta kekayaan tersebut, terdapat pengaturan khusus terkait kejahatan terhadap harta kekayaan yang terjadi dalam lingkup keluarga. Pengaturan tersebut, dapat ditemukan dalam Pasal 367 KUHP terkait pencurian dalam keluarga dan Pasal 376 KUHP terkait penggelapan dalam keluarga. Dalam Pasal 367 KUHP, diatur bahwa:

(1) Jika pembuat atau pembantu dari salah satu kejahatan dalam bab ini adalah suami (istri) dan orang yang terkena kejahatan dan tidak terpisah meja dan ranjang atau terpisah harta kekayaan, maka terhadap pembuat atau pembantu itu tidak mungkin diadakan tuntutan pidana.

(2) Jika dia adalah suami (istri) yang terpisah meja dan ranjang atau terpisah harta kekayaan, atau jika dia adalah keluarga sedarah atau semenda, baik dalam garis lurus maupun garis menyimpang derajat kedua, maka terhadap orang itu hanya mungkin diadakan penuntutan jika ada pengaduan yang terkena kejahatan.

(3) Jika menurut lembaga matriarkal, kekuasaan bapak dilakukan oleh orang lain daripada bapak kandung (sendiri), maka ketentuan ayat di atas berlaku juga bagi orang itu.

Berdasarkan ketentuan di dalam Pasal 367 KUHP tersebut, dapat dimaknai, bahwa:

1. Ketika seorang suami/istri melakukan/membantu pencurian terhadap pasangannya, maka terhadap suami/istri tersebut tidak dapat dituntut, kecuali pasangan tersebut pisah meja dan ranjang atau terpisah harta kekayaannya. Penggunaan frasa "atau" tersebut berkonsekuensi yuridis bersifat alternatif, artinya ketika pasangan tersebut telah pisah meja dan ranjang atau terpisah harta kekayaannya, maka barulah bisa dilakukan penuntutan. Penuntutan tersebut, juga hanya bisa dilakukan ketika ada pengaduan dari suami/istri yang merupakan korban dari pencurian tersebut.

2. Ketika terdapat terdakwa terkait tindak pidana pencurian yang memiliki hubungan keluarga sedarah atau semenda, baik dalam garis lurus maupun garis menyimpang derajat kedua dengan korbannya, maka penuntutan hanya bisa dilakukan, ketika terdapat pengaduan dari korban tersebut. Adapun 
yang dimaksud dalam hubungan keluarga sedarah atau semenda, baik dalam garis lurus maupun garis menyimpang derajat kedua adalah:

I. Hubungan keluarga sedarah dalam garis lurus diklasifikasikan menjadi dua, yaitu:

- Hubungan keluarga sedarah ke atas

Hubungan keluarga sedarah ke atas sampai derajat kedua terdiri dari bapak, ibu, kakek, dan nenek. Hal ini diatur dalam Pasal 293 Burgerlijk Wetboek (BW).

- Hubungan keluarga sedarah ke bawah

Hubungan keluarga sedarah ke bawah sampai derajat kedua terdiri dari anak dan cucu. Pasal 293 BW.

II. Hubungan keluarga garis menyimpang sampai derajat kedua terdiri dari saudara, baik laki-laki maupun perempuan. Berkaitan dengan hubungan ini diatur di dalam Pasal 293 BW.

III. Hubungan keluarga semenda dalam garis keturunan lurus diklasifikasikan menjadi dua, yaitu:

- Hubungan keluarga semenda ke atas

Hubungan keluarga semenda ke atas sampai derajat kedua terdiri dari mertua (ayah dan ibu dari suai/istri) dan orang tua dari mertua (kakek dari suami/istri). Berkaitan dengan hubungan ini diatur dalam Pasal 295 BW jo. 296 BW.

- Hubungan keluarga semenda ke bawah

Hubungan keluarga semenda ke bawah sampai derajat kedua terdiri dari anak angkat dan anak dari anak angkat. Berkaitan dengan hubungan ini diatur dalam Pasal 295 BW jo. 296 BW.

IV. Hubungan semenda garis menyimpang sampai derajat kedua terdiri dari saudara ipar laki-laki, maupun saudara ipar perempuan. Berkaitan dengan hubungan ini diatur dalam Pasal 295 BW jo. 296 BW.

3. Di Indonesia, terdapat beberapa wilayah yang keturunannya bersifat matrilineal. Dalam hal tersebut, kekuasaan ayah dilakukan oleh orang lain dari ayah kandung, seperti melalui paman. Dalam suatu masyarakat hukum adat tersebut, maka paman yang menggantikan kedudukan dari bapak 
kandung. Dalam hal tersebut, maka paman dapat melakukan pengaduan kalau dalam keluarga itu terjadi pencurian yang dilakukan oleh anggota keluarga itu sendiri. Hal ini sebagai penyesuaian antara hukum pidana nasional dengan hukum adat matrilineal tersebut.

Dengan demikian, dapat disimpulkan, bahwa terkait adanya tindak pidana pencurian dalam keluarga, wajib adanya pengaduan sesuai dengan pengaturan di dalam Pasal 367 KUHP. Apabila tidak ada pengaduan dari korban, maka konsekuensi yuridisnya adalah tidak mungkin dilakukannya penuntutan terhadap terdakwa yang notabene masih merupakan anggota keluarga dari korban itu sendiri. Hal inilah yang menyebabkan delik dalam Pasal 367 KUHP ini tergolong sebagai delik aduan, khususnya delik aduan realtif.

Jika melihat dalam kejahatan terhadap harta kekayaan pada lingkup keluarga yang lain yaitu penggelapan dalam keluarga, maka akan ditemukan pengaturan yang sama. Di dalam Pasal 376 KUHP, disebutkan bahwa: “Ketentuan dalam pasal 367 berlaku bagi kejahatan-kejahatan yang dirumuskan dalam bab ini." Hal ini berarti, penuntutan terhadap terdakwa pada penggelapan dalam lingkup keluarga juga harus terdapat pengaduan. Tanpa adanya pengaduan dari korban yang notabene merupakan anggota keluarga, maka terdakwa dari penggelapan dalam keluarga tersebut tidak dapat dituntut. Hal ini berarti, delik penggelapan dalam keluarga ini juga tergolong sebagai delik aduan relatif.

Dengan adanya kewajiban pengaduan dari korban yang notabene merupakan anggota keluarga dari terdakwa kejahatan terhadap harta kekayaan dalam lingkup keluarga, maka bisa dikatakan, bahwa keterangan dari korban ini merupakan suatu hal yang harus dihadirkan sebagai alat bukti dalam persidangan. Tentu akan sangat aneh, ketika korban yang notabene wajib melakukan pengaduan, namun ternyata tidak dihadirkan oleh penuntut umum sebagai saksi. Dengan tidak dihadirkannya korban sebagai saksi, sebenarnya secara tidak langsung bisa dikatakan, bahwa tidak ada pihak yang dirugikan dari adanya pencurian/penggelapan dalam lingkup keluarga tersebut, karena mengingat delik ini adalah delik aduan pula. Dengan logika hukum tersebut, maka bisa ditarik benang merah, bahwa dalam kejahatan terhadap harta kekayaan pada lingkup keluarga, kehadiran korban yang notabene merupakan anggota keluarga dari terdakwa merupakan suatu keharusan. 
Berdasarkan analisis tersebut, dapat dilihat, bahwa kehadiran keterangan korban sebagai saksi dalam kejahatan terhadap harta kekayaan pada lingkup keluarga merupakan suatu hal yang wajib ada, namun ternyata hal ini memiliki problematika hukum yaitu adanya pertentangan dengan hukum formil yang diatur dalam KUHAP. Seperti yang dijelaskan di atas, bahwa pada intinya di dalam Pasal 168 jo. 169 KUHAP, diatur bahwa:

1. Saksi dari keluarga sedarah atau semenda dalam garis lurus ke atas atau ke bawah sampai derajat ketiga dari terdakwa berpotensi untuk tidak dapat disumpah

2. Saksi dari keluarga sedarah atau semenda dalam garis lurus ke samping sampai derajat ketiga dari terdakwa berpotensi untuk tidak dapat disumpah.

Padahal, jika merujuk pada ketentuan dalam Pasal 367 jo. 376 KUHP, disebutkan bahwa dimaksud korban dalam kejahatan terhadap harta kekayaan dalam lingkup keluarga adalah:

1. Orang sedarah atau semenda dalam garis lurus ke atas atau ke bawah sampai derajat kedua

2. Orang dari keluarga sedarah atau semenda dalam garis lurus ke samping sampai derajat kedua

Hal ini berarti, korban yang notabene merupakan anggota keluarga dari terdakwa merupakan irisan dari pihak-pihak yang keterangannya berpotensi tidak dapat disumpah. Berikut gambar irisan tersebut: 


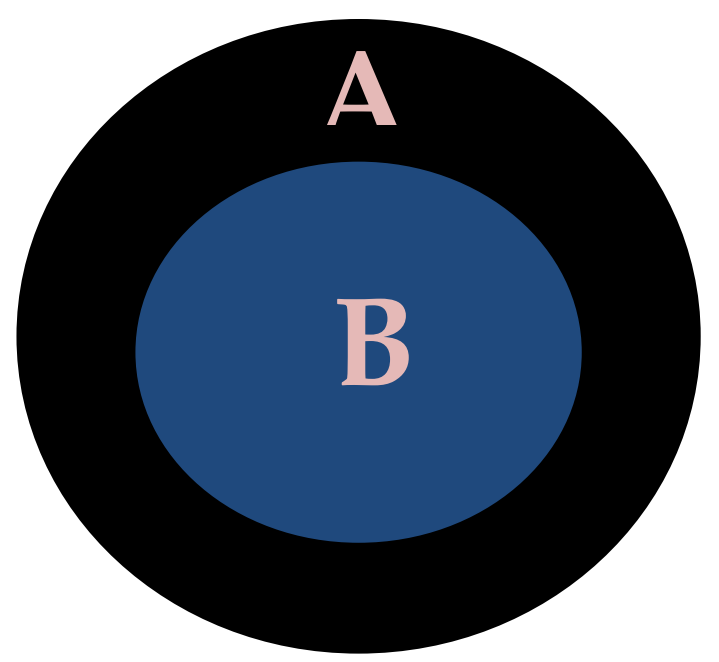

Gambar 1. Irisan Pihak yang berpotensi tidak dapat disumpah

Keterangan:

A = Merupakan anggota keluarga sedarah atau semenda dalam garis lurus ke atas atau ke bawah sampai derajat ketiga dan keluarga sedarah atau semenda dalam garis lurus ke samping sampai derajat ketiga

$\mathrm{B}=$ Merupakan anggota keluarga sedarah atau semenda dalam garis lurus ke atas atau ke bawah sampai derajat kedua dan keluarga sedarah atau semenda dalam garis lurus ke samping sampai derajat kedua

Memang di dalam Pasal 169 ayat (1) KUHAP, diatur, bahwa ketiga kelompok orang tersebut dapat memberikan keterangan dibawah sumpah sepanjang mendapat persetujuan dari penuntut umum dan terdakwa, namun hal ini berarti terdapat potensi, dimana korban yang notabene merupakan anggota keluarga dari terdakwa keterangannya tidak dapat disumpah, apabila jaksa/terdakwa menolak saksi tersebut untuk disumpah. Seperti yang telah diuraikan di atas, maka terdapat tiga posibilitas terkait keterangan saksi yang tidak disumpah, yaitu:

a) Ketika ada persesuaian dengan saksi lain, maka keterangan saksi tersebut (korban) bersifat dependen

b) Ketika bersesuaian dengan alat bukti surat dan/atau keterangan terdakwa, maka keterangan saksi tersebut (korban) bernilai sebagai bukti petunjuk

c) Ketika tidak bersesuaian dengan alat bukti lain, maka tidak memiliki nilai sebagai alat bukti.

Cum adsunt testimonia rerum, quid opus est verbist, yang berarti saat bukti dan fakta 
sudah ada, apalah guna kata-kata. ${ }^{25}$ Sebuah postulat hukum yang memiliki kedalaman makna, bahwa untuk membuktikan suatu argumentasi hukum, maka harus ditunjukkan dengan bukti yang nyata. Dalam hal ini, bukti nyata dari argumentasi hukum, bahwa keterangan korban yang notabene merupakan saksi dapat disumpah, meski merupakan keluarga dari terdakwa dalam kejahatan terhadap harta kekayaan pada lingkup keluarga dapat dilihat dalam Putusan Pengadilan Negeri Sidoarjo Nomor 835/Pid.B/2010/PN.Sda. terkait pencurian dalam keluarga dan Putusan Pengadilan Negeri Pematang Siantar Nomor 102/Pid.B/2018/PN Pms terkait penggelapan dalam keluarga.

Dalam Putusan Pengadilan Negeri Sidoarjo Nomor 835/Pid.B/2010/PN.Sda., diuraikan, bahwa Agus Setiawan alias Man Bin Sukardi mencuri barang-barang milik kakak iparnya, yaitu Sugiyanto. Pada saat sidang, Sugiyanto dihadirkan sebagai saksi, namun karena Agus Setiawan alias Man Bin Sukardi yang notabene adik iparnya tidak keberatan, maka kesaksian Sugiyanto kemudian dipertimbangkan oleh hakim sebagai salah satu alat bukti.

Hal serupa juga dapat dilihat dalam Putusan Pengadilan Negeri Pematang Siantar Nomor 102/Pid.B/2018/PN Pms. Dalam Putusan Pengadilan Negeri Pematang Siantar Nomor 102/Pid.B/2018/PN Pms, Noveri Hamonangan Sibuea didakwa melakukan penggelapan terhadap kursi-kursi milik Tiodor Tambunan yang notabene adalah merupakan ibu tiri dari Noveri Hamonangan Sibuea. Dalam persidangan, Tiodor Tambunan sebagai korban yang notabene adalah ibu dari Tiodor Tambunan dihadirkan sebagai saksi, namun karena Noveri Hamonangan Sibuea yang notabene adalah anak tiri dari saksi tidak keberatan, maka kesaksian Noveri Hamonangan Sibuea kemudian dipertimbangkan oleh hakim sebagai salah satu alat bukti.

\section{KESIMPULAN}

Berdasarkan prinsip-prinsip dalam hukum pidana, maka keterangan saksi berdasarkan nilai pembuktiannya dapat dibedakan menjadi 5 kelompok yaitu Keterangan saksi yang tidak bernilai pembuktian, Keterangan saksi yang bernilai

25 Ekky Chariminsyah, Hak Tersangka/Terdakwa Untuk Mengajukan Saksi A De Charge (Saksi Meringankan) Dalam Proses Perkara Pidana, Lex Crimen, Vol 5, No 2, Februari 2016, h. 37. 
pembuktian yang sifatnya independen dan diterima sebagai alat bukti keterangan saksi, keterangan saksi yang bernilai pembuktian yang sifatnya dependen dan diterima sebagai alat bukti keterangan saksi, Keterangan saksi yang bernilai pembuktian yang sifatnya dependen dan tidak dapat diterima sebagai alat bukti keterangan saksi, namun diterima sebagai alat bukti petunjuk, dan Keterangan saksi yang bernilai pembuktian yang sifatnya independen serta memiliki persesuaian dan diterima sebagai alat bukti keterangan saksi dan diterima pula sebagai alat bukti petunjuk.

Pada kejahatan terhadap harta kekayaan dalam lingkungan keluarga, maka terdakwa pasti merupakan anggota keluar dari korban. Dalam hal tersebut, kekuatan pembuktian dari keterangan korban tersebut memiliki tiga posibilitas, yaitu Ketika ada persesuaian dengan saksi lain, maka keterangan saksi tersebut (korban) bersifat dependen, atau Ketika bersesuaian dengan alat bukti surat, maka keterangan saksi tersebut (korban) bernilai sebagai bukti petunjuk, atau Ketika tidak bersesuaian dengan alat bukti lain, maka tidak memiliki nilai.

\section{DAFTAR PUSTAKA}

Alamanda, Azharia Putty. (2017). Kesesuaian Penggunaan Saksi Verbalisan Serta Pertimbangan Hukum Hakim Dalam Menjatuhkan Putusan (Studi Putusan Nomor 1131/Pid.An/2013/Jkt.Sel). Jurnal Verstek, 5(3), 102-109.

Chariminsyah, Ekky. Hak Tersangka/Terdakwa Untuk Mengajukan Saksi A De Charge (Saksi Meringankan) Dalam Proses Perkara Pidana. Lex Crimen, 5(2),37-45.

Chazawi, Adami. Hukum Pembuktian Tindak Pidana Korupsi. Bandung, Indonesia: PT.Alumni.

Hartini, Sri. (2007). Korban Penyalahgunaan Kewenangan Rezim Orde Baru. Journal Civics, 4(2), 51-66.

Kurniawan, Faizal, Xavier Nugraha, Bagus Oktafian Abrianto, dan Syifa Ramadhanti. (2020). The Right To Access Banking Data In A Claim For A Division Of Combined Assets That Is Filed Separately From A Divorce 
Claim. Yustisia, 9(1),46-75.

Marzuki, Peter Mahmud. (2005). Penelitian Hukum Edisi Revisi. Jakarta, Indonesia: Kencana Prenada Media.

Meyrina, Rr. Susana Andi. (2017). Restorative Justice Dalam Peradilan Anak Berdasarkan Undang-Undang No.11 Tahun 2012. Jurnal Penelitian Hukum De Jure, 17(1),92-117.

Mulyadi, Lilik. Hukum Acara Pidana. Bandung, Indonesia:PT Citra Aditya Bakti.

Nugraha, Xavier , Risdiana Izzaty, dan Annida Aqila. (2019). Rekonstruksi Batas Usia Minimal Perkawinan Sebagai Bentuk Perlindungan Hukum. Lex Scientia, 3(1), 40-54.

Nugroho, Bastianto. (2017). Peranan Alat Bukti Dalam Perkara Pidana Dalam Putusan Hakim Menurut KUHAP. Yuridika, 32(1),17-36.

Oliveira, Marcus Vinicius Xavier de. (2019). Os Direitos Absolutos No Contexto Do Direito Internacional Dos Direitos Humanos. Revista jurídica de la Secretaría del Tribunal Permanente de Revisión, 7(13),95-119.

Priyambodo, Yulius Eko. (2014). Homo Ridens: Suatu Tawaran 'Menjadi' Manusia Di Zaman Ini. Melintas: An International Journal of Philosophy and Religion, 30(1), 45-69.

Purnomo, Wahyu, Rr Herini Siti Aisyah, Thoriq Mulahela, dan Xavier Nugraha. Analysis of Lawsuit Against the Factual Action which Conducted by Military after Law Number 30 Year 2014 Concerning Government Administration. UNRAM Law Review, 4(1),17-25.

Purwanti, Evi Yulia dan Eka Widyaningsih. (2019). Analisis Faktor Ekonomi Yang Mempengaruhi Kriminalitas Di Jawa Timur. JEQU, 9(2), 154-177.

Remincel. (2019). Kedudukan Saksi Dalam Hukum Pidana. Ensiklopedia of Journal, 1(2 edisi 2), 268-273.

Runtuwene, Oktavianus Garry. (2012). Hak Dan Kewajiban Yang Mengikat Terhadap Saksi Di Dalam Praktik Persidangan Pidana. Lex Crimen, $1(4), 142-161$.

Soekanto, Soerjono. (1989). Pengantar Penelitian Hukum.Jakarta, Indonesia: UI Press.

Suprantio, Steven. (2014). Daya Ikat Putusan Mahkamah Konstitusi Tentang "Testimonium de Auditu". Jurnal Yudisial, 7(1), 34-52.

Wangke, Asprianti. Kedudukan Saksi De Auditu Dalam Praktik Peradilan Menurut Hukum Acara Pidana. Lex Crimen, (6),146-154. 